\title{
THE LXX OF 1 CHRONICLES 5:1-2 AS AN EXPOSITION OF GENESIS 48-49
}

\section{P.J. Williams}

In the middle of the genealogical survey of history in the opening nine chapters of $1 \mathrm{Chronicles}$ we encounter details of the descendants of Reuben (5:1-10). At the very beginning of his genealogy Reuben is described as the firstborn of Jacob. However, before his genealogy proper commences, there is a brief note explaining in what sense he may still be called 'firstborn', despite his misconduct recorded in Genesis 35:22. The MT of 1 Chronicles 5:1-2 reads:

And the children of Reuben the firstborn of Israel (for he was the firstborn, and when he defiled his father's bed his

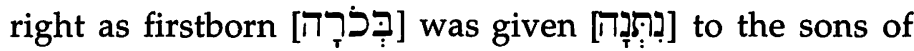
Joseph, son of Israel, but not so as to be reckoned in the genealogy as firstborn [דָּרָה]]. For Judah was great among his brothers, and there came a leader from him, but the right as firstborn [דָּּּרָ] belonged to Joseph) [my translation].

In these verses the LXX differs from the MT in several ways. For the MT's 'when he defiled', the LXX reads 'when he ascended' ('่v $\tau \hat{\varphi}$ ó $\alpha \beta \hat{\eta} v \alpha \mathrm{l}$ ); for 'was given', it has 'he gave'

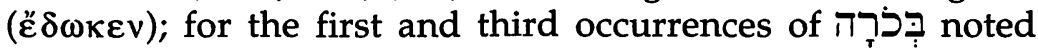

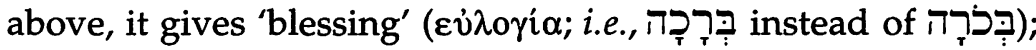

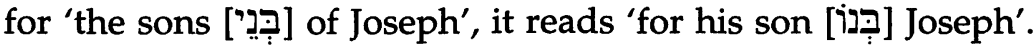
The textual apparatus of $B H S$ notes variants in the latter two places. In the case of the variation between 'right as firstborn'

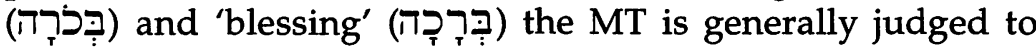
contain the earlier reading. 1 This is because the whole purpose

1Thus E.L. Curtis and A.A. Madsen, The Books of Chronicles (International Critical Commentary; Edinburgh: T. \& T. Clark, 1910) 121. See also L.C. Allen, The Greek Chronicles, The Relation of the Septuagint of I and II 
of 1 Chronicles $5: 1-2$ is to explain the status of the birthright among Jacob's sons and not to consider their blessing. MT's reading alone suits the context. However, the presence of a cluster of differences between the MT and the LXX at this point requires an explanation. The mention of 'blessing' in connection with Joseph has been traced to Genesis 48:15.2 Furthermore, the Greek translation in 1 Chronicles 5:1, 'when

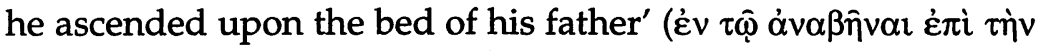

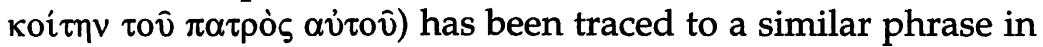
Genesis 49:4: 'for you ascended upon the bed of your father'

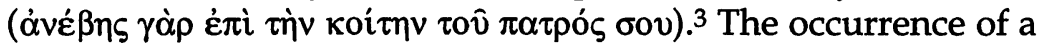
variant based on Genesis 48 and of one based on Genesis 49 in such proximity suggests that it is profitable to consider all the variants in the context of Genesis $48-49$ as a whole.

In fact, several of the distinctives of the LXX can be regarded as influenced by an overall reading of Genesis 48 and 49. Both these chapters have in common the themes of blessing and of being firstborn. Genesis 48 is about Jacob's blessing of Joseph and of his two sons Manasseh and Ephraim. In this blessing, Jacob gives precedence not to the firstborn Manasseh but to the younger son Ephraim. The two motifs of primogeniture and blessing are juxtaposed in Genesis 48:14-15.

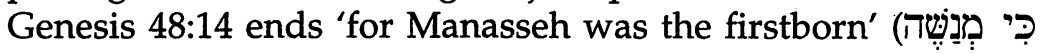
הַבְכָוֹר [ [the phrase is omitted in the LXX]), and 48:15 opens 'and

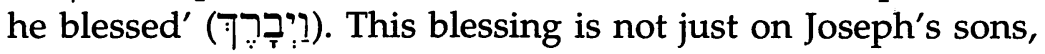
but also on Joseph himself ( $c f .1$ Ch. 5:1 LXX). Yet the blessing is closely related to primogeniture. In Genesis 48:5 Jacob claims that 'Ephraim and Manasseh' (note the order with the firstborn second) shall be for him like Reuben and Simeon. This could be read as saying that Joseph's second- and first-born shall be like Jacob's first- and second-born, respectively. In Genesis 48:22, whatever its interpretation, it seems that Joseph is given an inheritance over what his brothers have. Such an inheritance might be closely associated with the rights of firstborn. In this

Chronicles to the Massoretic Text: Part II, Textual Criticism (Supplements to Vetus Testamentum XXVII; Leiden: E.J. Brill, 1974) 107.

2Allen, The Greek Chronicles: Part II, 107.

${ }^{3}$ L.C. Allen, The Greek Chronicles: Part I, The Translator's Craft (Supplements to Vetus Testamentum XXV; Leiden: E.J. Brill, 1974) 70. 
light Genesis 49 could be read (and perhaps was read by the LXX) as suggesting that both rights as firstborn and blessing were bestowed on Joseph. Thus, though Reuben is mentioned as firstborn, he is strongly criticised (Gn. 49:3-4). On the other hand, it is Joseph who receives the fivefold blessing in Genesis 49:25-26. Thus, it is perhaps in these two chapters that we may trace the origin of the association of blessing and primogeniture in the LXX of 1 Chronicles. This also explains the other variants in 1 Chronicles:

(1) In the LXX of 1 Chronicles $5: 1$, 'son' is singular and refers to Joseph. This contrasts with the MT's plural, referring to Joseph's sons. This follows a contextual emphasis in Genesis 48-49 on Joseph as Jacob's special son. In Genesis 48:2, 19, and 49:22, 'son' occurs in the singular with reference to Joseph.

(2) The choice of the active 'gave' in the LXX for the MT's passive 'was given' could be seen as reflecting the active 'give' in Genesis 48:22.

(3) The variation already mentioned of 'when he ascended' for 'when he defiled' comes from the same context (Gn. 48:15).

Whether or not it is accepted that the variations shown by the LXX text derive from a contemplation of Genesis 48 and 49 , it is at the outset an open question whether these variants originate from the process of translation of the LXX or whether they were present in the LXX's Vorlage. Interestingly, some answer to this question comes from the various Greek and Hebrew words used for 'bed'. In Genesis 49:4 koi $\tau$ translates

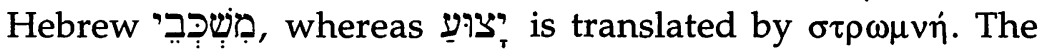

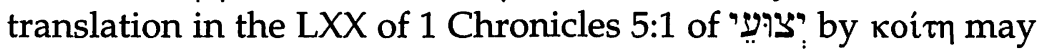
indicate that the Greek translator of 1 Chronicles had the Greek text of Genesis before him. If this was the case, then these variants arose at the stage of the translation of the LXX and not at the level of its Vorlage. In conclusion, the variants in the LXX of 1 Chronicles 5:1-2 are interesting exegetical phenomena, but in this case the LXX should not be used to emend the MT. 